\title{
Pengaruh Ekonomi Terhadap Perceraian di Kabupaten Pacitan | Mansur Azis PENGARUH EKONOMI TERHADAP PERCERAIAN DI KABUPATEN PACITAN
}

\author{
Mansur Azis \\ Institut Agama Islam Negeri Ponorogo, Indonesia \\ mansur4215@iainponorogo.ac.id
}

\begin{abstract}
:
Marriage is a social bond or legal agreement between individuals that forms kinship. Marriage aims to announce and give a new status to a married couple to others, so that this couple is accepted and recognized as a legal partner according to law, religion, custom and state. With the husband and wife bond, there will be continuous interaction between these two different people, this interaction can also determine harmony in the family, and disharmony in the family that can have an impact on divorce. The purpose of this study was to analyze the economic effect in terms of education, type of work and income on divorce in Pacitan district. The research method used is quantitative research methods. The sampling technique uses cluster sampling. The sample in this study was the people of the Pacitan district who divorced in 2019. Data collection techniques used questionnaires, documentation interviews and observations. The method of analysis uses descriptive statistics, classical assumption test, multiple regression analysis, $t$ test, $F$ test, and coefficient of determination (R2). The results of this study indicate that 1) Education has a significant effect on divorce in Pacitan Regency in 2019, 2) Type of work has no significant effect on divorce in Pacitan Regency in 2019, 3) Income has a significant effect on divorce in Pacitan Regency in 2019, 4)) Economy (Education, type of work, and income) have a significant effect on divorce in Pacitan district in 2019 with a large influence of 38.3\% while the remaining $72.7 \%$ is influenced by other variables outside of this research model.
\end{abstract}

Keywords: Economy, Divorce, Pacitan

\section{Abstrak:}

Pernikahan adalah ikatan perjanjian hukum antar pribadi yang membentuk hubungan kekerabatan. Pernikahan bertujuan untuk mengumumkan dan memberikan status baru pada pasangan suami istri kepada orang lain, supaya pasangan ini diterima dan diakui statusnya sebagai pasangan yang sah menurut hukum, agama, adat, dan negara. Dengan adanya ikatan suami istri maka akan terjadi interaksi terus menerus antara dua insan yang berbeda ini, interaksi ini juga dapat menentukan keharmonisan dalam keluarga, dan ketidak harmonisan dalam keluarga yang bisa berdampak pada perceraian. Tujuan penelitian ini adalah untuk menganalisis pengaruh ekonomi yang di tinjau dari segi pendidikan, jenispekerjaan dan pendapatan terhadap perceraian di kabupaten Pacitan. Metode penelitian yang digunakan adalah metode penelitian kuantitatif. Tekhnik sampling menggunakan cluster sampling. Sampel dalam penelitian ini adalah masyarakat kabupaten pacitan yang melakukan perceraian ditahun 2019. Tekhnik pengumpulan data menggunakan angket, wawancara okumentasi dan observasi. Metode analisis menggunakan statistik deskriptif, uji asumsi klasik, analisis regresi berganda, uji t, uji $F$, dan koefesien determinasi $\left(R^{2}\right)$. Hasil penelitian ini menunjukkan bahwa 1) Pendidikan berpengaruh signifikan terhadap perceraian di kabupaten Pacitan tahun 2019, 2) Jenis pekerjaan tidak berpengaruh signifikan terhadap perceraian di kabupaten Pacitan tahun 2019, 3) pendapatan berpengaruh signifikan terhadap perceraian di kabupaten Pacitan tahun 2019, 4) ) Ekonomi (Pendidikan, Jenis Pekerjaan, dan Pendapatan) berpengaruh signifikan 
Pengaruh Ekonomi Terhadap Perceraian di Kabupaten Pacitan | Mansur Azis terhadap perceraian di kabupaten Pacitan tahun 2019 dengan besarnya pengaruh 38,3\% sedangkan sisanya sebesar 72,7\% dipengaruhi oleh variabel lain di luar model penelitian ini. Kata Kunci: Ekonomi, Perceraian, Pacitan 


\section{A. PENDAHULUAN}

Pernikahan adalah pengabungan dua insan yang berbeda yaitu antara laki-laki dan perempuan yang mempunyai tujuan yang sama dalam membangun bahtera rumah tangga. Saleh Al-Utsaimin, berpendapat bahwa nikah adalah, "pertalian hubungan antara laki-laki dan perempuan dengan maksud agar masing-masing dapat menikmati yang lain dan untuk membentuk keluarga yang saleh dan membangun masyarakat yang bersih". ${ }^{1}$ Pernikahan pada hakikatnya secara sederhana merupakan bentuk kerjasama kehidupan antara laki-laki dan perempuan di dalam masyarakat. Pernikahan juga bisa disebut ikatan sosial atau ikatan perjanjian hukum antar pribadi yang membentuk hubungan kekerabatan. Pernikahan bertujuan untuk mengumumkan dan memberikan status baru pada pasangan suami istri kepada orang lain, supaya pasangan ini diterima dan diakui statusnya sebagai pasangan yang sah menurut hukum, agama, adat, dan negara.

Dengan adanya pernikahan maka akan terbentuk sebuah keluarga, keluarga adalah "unit terkecil dari masyarakat yang di dalamnya terdapat kepala dan angota rumah tangga yang hidup di bawah satu atap dalam dan saling membutuhkan". ${ }^{2}$ Maka dari itu perlu adanya peran dan fungsi dari masing-masing anggota keluarga, terutama fungsi atau peran sebagai suami dan istri. Dengan adanya suami istri maka akan terjadi interaksi terus menerus antara dua insan yang berbeda ini, interaksi ini juga dapat menentukan keharmonisan dalam keluarga, dan juga ketidak harmonisan dalam keluarga yang bisa berdampak pada perceraian. Perceraian bisa diartikan putusnya hubungan antara suami dan istri, pecahnya suatu unit keluarga, atau retaknya struktur peran sosial apabila suami istri gagal menjalankan kewajiban dan peran mereka masingmasing. UU no. 1/ 1974 tentang perkawinan menjelaskan bawa, perceraian yaitu putusnya ikatan perkawinan.

Perceraian saat ini sudah sangat memprihatinkan, seperti yang terjadi di Kabupaten Pacitan. Data menunjukkan selama tahun 2018 tercatat ada 1.071 kasus perceraian, dengan 752 kasus cerai gugat atau diajukan istri dan sisanya 319 kasus karena permohonan suami. Jumlah ini meningkat tajam dibandingkan tahun 2017 dimana ada 912 kasus perceraian. Jumlah perceraian di Pacitan juga meningkat dalam

\footnotetext{
1 "Fiqih Pernikahan: Pengertian, Hukum dan Rukunnya," DalamIslam.com, 8 Juni 2016, https://alamislam.com/hukum-islam/pernikahan/fiqih-pernikahan.

2 "Keluarga," dalam Wikipedia bahasa Indonesia, ensiklopedia bebas, 24 Februari 2021, https://id.wikipedia.org/w/index.php?title=Keluarga\&oldid=18024813.
} 
Pengaruh Ekonomi Terhadap Perceraian di Kabupaten Pacitan | Mansur Azis beberapa tahun terakhir. Pada tahun 2015 tercatat ada 929 kasus perceraian dan tahun 2016 ada 910 kasus. $^{3}$ Pada awal tahun 2019 yang masuk di Pengadilan Agama Pacitan ada 479 kasus dan di mumungkinkan akan bertambah lagi. ${ }^{4}$

Fenomena perceraian di Kabupaten Pacitan disebabkan oleh banyak faktor. Menurut Kabalmay, ketidakadanya keseimbangan dari sisi keuangan menjadi salah satu masalah utama yang sering dihadapi dalam keluarga. ${ }^{5}$ Padahal menurut data setatistik dari situs resmi BPS Pacitan menunjukkan bahwa ekonomi kabupaten pacitan meningkat 5,21\%. Dari tahun sebelumnya.

Selain itu pendidikan juga dapat mempengaruhi hubungan pernikahan, seperti yang dinyatakan Newman \& Newman, "Angka perceraian yamg paling dominan ditempati keluraga yang memiliki pendapatan dan tingkat pendidikan rendah dibandingkan mereka yang ada dikalangan menengah ke atas". ${ }^{6}$ Pendidikan yang rendah membuat mereka sulit bersaing untuk mendapatkan pekerjaan yang layak, sehingga mempengaruhi kesejahteraan keluarga. Pendidikan yang rendah dapat mempengaruhi jenis pekerjaan yang didapat, begitu juga jenis pekerjaan akan berdampak pada tingkat pendapatan, sehingga pendapatan juga akan berdampak pada kondisi ekonomi keluarga. Kondisi ekonomi atau bisa disebut tingkat ekonomi keluarga dapat mempengaruhi hubungan suami istri. Padahal Kabupaten Pacitan memiliki cukup SDM yang sangat peotensial dalam mendongkrak ekonomi yaitu mempunyai 357.510 ribu jiwa usia produktif. $^{7}$

Berdasarkan uraian di atas peneliti tertarik untuk melakukan penelitian yang berjudul "Pengaruh Tingkat Ekonomi Terhadap Perceraian di Kabupaten Pacitan"

\footnotetext{
3 "Perceraian di Pacitan Kian Mengkhawatirkan, Selama 2018 Ada 1.071 Janda Baru," diakses 11 Juni 2021, https://halopacitan.com/read/perceraian-di-pacitan-kian-mengkhawatirkan-selama-2018-ada-1071-janda-baru.

4 “2 Hari Awal Ramadhan, PA Pacitan Tangani 30 Perkara Perceraian Teras Jatim,” 7 Mei 2019, https://www.terasjatim.com/2-hari-awal-ramadhan-pa-pacitan-tangani-30-perkara-perceraian/.

${ }^{5}$ Husin Anang Kabalmay, "Kebutuhan Ekonomi dan Kaitannya Dengan Perceraian (Studi atas Cerai Gugat di Pengadilan Agama Ambon)," no. 1 (2015): 21.

${ }^{6}$ Barbara M. Newman dan Philip R. Newman, Development through life: a psychosocial approach, 10e ed. (Australia ; Belmont, CA: Wadsworth/Cengage Learning, 2009), 50.

7 "Sekilas Profil Kabupaten Pacitan," Pacitan TRIP (blog), 9 November 2015, https://www.pacitantrip.com/profil-kabupaten-pacitan/.
} 
Pengaruh Ekonomi Terhadap Perceraian di Kabupaten Pacitan | Mansur Azis

\section{B. TEORI TANG RELEVAN}

\section{Perceraian}

\section{a. Pengertian perceraian}

Perceraian dalam Islam disebut dengan tala $>q$ atau firqoh. Kata talak adalah kata serapan dari ahasa arab (إطُلَ)ق $)$ itla $>q$ yang berarti meninggalkan atau. melepaskan, dalam istilah syara', talak adalah memutuskan tali perkawinan, atau hubungan perkawinan yang rusak.

Menurut Sayyid Sabiq, talak artinya mengakhiri hubungan perkawinan atau memutuskan tali perkawinan. ${ }^{8}$ Sedangkan menurut Zainuddin Ibn 'Abdul Aziz, talak adalah memutuskan tali pernikahan dengan mengucapkan kata-kata talak. ${ }^{9}$ Dari pendapat ilmuwan di atas dapat diambil kesimpulan bahwa perceraian yaitu terputusnya tali/ikatan pernikahan atas kehendak suami atau istri.

Di Indonesia perceraian di bagi menjadi dua jenis yaitu cerai talak dan cerai gugat. Cerai talak perceraian yang dijatuhkan oleh seorang suami kepada istrinya yang perkawinannya dilaksanakan menurut agama Islam (Pasal 14 PP No. 9/1975). Cerai gugat adalah perceraian yang dilakukan oleh seorang istri yang melakukan perkawinan menurut agama Islam dan oleh seorang suami atau seorang istri yang melangsungkan perkawinannya menurut agamanya dan kepercayaan itu selain agama Islam (penjelasan Pasal 20 ayat (1) PP No. 9/1975). Cerai talak dan cerai gugat hanya dapat dilakukan di depan Sidang Pengadilan (Pasal 39 ayat (1) PP No. 9).

\section{b. Dasar hukum perceraian}

1) Dasar hukum perceraian dalam Islam

Dasar hukum perceraian dalam Islam tertera dalam Al-Quran surat At-

Talaq ayat 1:



Hai Nabi bila kamu mentalaq istrimu, maka talaklah dia sewaktu masuk ke dalam iddahnya ${ }^{10}$.

8 Sayyid Sabiq, "Fiqh as Sunnah.pdf," 9, diakses 11 Juni 2021, https://docs.google.com/viewer?a=v\&pid=sites\&srcid=ZGVmYXVsdGRvbWFpbnxtZW50b3Jjb3VuY2lsb GlicmFyeXxneDphN2Q2ZTkwZDYwNjc1NGE.

${ }^{9}$ Zainuddin bin 'Abdul 'Azizz al-Maribari, Fathul Mu'in bi Syarhi Quratul-'Aini (Bairut: Dar Ibn Hazm, 2004), 112.

10 “Qur'an Kemenag," 942, diakses 11 Juni 2021, https://quran.kemenag.go.id/. 
Pengaruh Ekonomi Terhadap Perceraian di Kabupaten Pacitan | Mansur Azis walaupun perceraian tertera di dalam Al-Quran dan banyak ayat-ayat yang berbicara mengenai perceraian akan tetapi tidak ada ayat yang menganjurkan atau melarang perceraian, ayat Al-Quran hanya mengatur jika talak atau cerai terjadi.

Hukum talak dalam Islam yaitu mubah, meskipun tidak ada ayat alQur'an yang menyuruh atau melarang perceraian, akan tetapi perceraian itu termasuk perbuatan yang tidak disenangi oleh baginda Rasulullah SAW. Dan ini dapan menjelaskan bahwa perceraian itu hukumnya makruh. Karena sesungguhnya Rasulullah SAW ketidaksenang pada perceraian, hal itu dapat terlihat dalam hadisnya dari Ibnu Umar. Sabda Nabi:

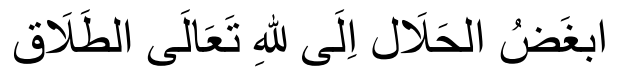

Perbuatan halal yang paling dibenci Allah adalah talak. ${ }^{11}$

Dari hadis ini kita bisa diartikan bahwasanya perceraian dalam Islam sangat tidak dianjurkan, selain itu perceraian mengakibatkan terputusnya silaturahim yang sudah terjalin diantara suami istri, dan juga keluarga.

2) Dasar hukum perceraian di Indonesia

Di Indonesia perceraian sudah diatur di dalam undang-undang yaitu UU No. 1 Tahun 1974 tentang perkawinan yang berbunyi "Perkawinan dapat putus karena kematian, perceraian dan, atas keputusan Pengadilan”.

Pasal 39 ayat 1 UU No. 1 Tahun 1974 tentang Perkawinan "Perceraian hanya dapat dilakukan didepan Sidang Pengadilan setelah Pengadilan yang bersangkutan berusaha dan tidak berhasil mendamaikan kedua belah pihak".

Selain itu juga terdapat dalam PP No 9 Tahun 1975 tentang Pelaksanaan UU No 1 Tahun 1974 tentang Perkawinan.

\section{c. Alasan- alasan perceraian.}

Alasan-asalan perceraian di dalan negara Indonesia telah diatur dalam Pasal 39 ayat 2 UU No. 1 tahun 1974 tentang Perkawinan Jo Pasal 19 Peraturan Pemerintah No. 9 Tahun 1975 Tentang Pelaksanaan Undang-Undang Nomor 1 Tahun 1974 Tentang Perkawinan yakni sebagai berikut:

1) Salah satu pihak berbuat zina atau menjadi pemabok, pemadat, penjudi dan lain sebagainya yang sukar disembuhkan;

${ }^{11}$ Abi Dawud, Sunan Abi Dawud, vol. 2 (Damsyik: Dar Ar-Risalah Al-Alamiyah, 2009), 1863. 
Pengaruh Ekonomi Terhadap Perceraian di Kabupaten Pacitan | Mansur Azis

2) Salah satu pihak meninggalkan yang lain selama 2 (dua) tahun berturut-turut tanpa izin pihak yang lain dan tanpa alasan yang sah atau karena hal lain diluar kemampuannya;

3) Salah satu pihak mendapat hukuman penjara 5 (lima) tahun atau hukuman yang lebih berat setelah perkawinan berlangsung;

4) Salah satu pihak melakukan kekejaman atau penganiayaan berat yang membahayakan terhadap pihak yang lain;

5) Salah satu pihak mendapat cacat badan atau, penyakit yang mengakibatkan tidak dapat menjalankan kewajibannya sebagai suami/isteri;

6) Antara suami dan isteri terus menerus terjadi perselisihan dan pertengkaran dan tidak ada harapan akan hidup rukun lagi dalam rumah-tangga;

Khusus yang beragama Islam, ada tambahan dua alasan perceraian selain alasan-alasan di atas, sebagaimana diatur dalam Pasal 116 Kompilasi Hukum Islam yaitu:

1) Suami melanggar taklik-talak;

2) Peralihan agama atau murtad yang menyebabkan terjadinya ketidakrukunan dalam rumah tangga.

Dengan kata lain, hakim tidak akan mengabulkan gugatan cerai di luar alasan-alasan di atas.

\section{d. Facktor-faktor perceraian}

Pada dasarnya ada beberapa faktor yang menyebabkan terjadinya perceraian diantaranya yaitu: ${ }^{12}$

1) Faktor usia (pernikahan dini)

2) Faktor ekonomi

3) Faktor keturunan

4) Faktor pendidikan

5) Faktor KDRT (kekerasan dalam rumah tangga)

6) Faktor pihak ketiga

${ }^{12}$ Armansyah Matondang, "Faktor-faktor yang Mengakibatkan Perceraian dalam Perkawinan," JPPUMA: Jurnal Ilmu Pemerintahan dan Sosial Politik UMA (Journal of Governance and Political Social UMA) 2, no. 2 (1 Desember 2014): 141-50 


\section{Tingkat Ekonomi Keluarga}

Pengaruh Ekonomi Terhadap Perceraian di Kabupaten Pacitan | Mansur Azis

\section{a. Pengertian ekonomi secara umum}

Ekonomi adalah ilmu mengenai asas-asas produksi, distribusi, dan pemakaian barang-barang serta kekayaan. ${ }^{13}$ Menurut Rosyidi, ilmu ekonomi adalah, "pengetahuan dan pengertian tentang gejala-gejala masyarakat yang merupakan salah satu cabang ilmu pengetahuan sosial." ${ }^{\text {"14 }}$ Menurut George Soul, ekonomi adalah, "ilmu sosial tentang prilaku manusia dalam kehidupan masyarakat dalam rangka mencapai kemakmuran dan kesejahteraan umumnya dan khususnya dalam usaha memenuhi kebutuhan". ${ }^{15}$ Sedangkan menurut Adam Smith, ilmu ekonomi adalah, "Ilmu yang mempelajari perilaku manusia dalam mencapai tujuan-tujuan tertentu dalam hidupnya dengan mengelola berbagai sumber daya terbatas atau tidak terbatas". ${ }^{16}$ Sedangkan Umer Chapra yang merupakan tokoh ekonomi Islam mengemukakan bahwa, "cabang dari ilmu pengetahuan yang sesuai dengan tujuan yang ditetapkan berdasarkan syariah dalam membantu manusia untuk mewujudkan kesejahteraannya melalui alokasi dan distribusi berbagai sumber daya alam yang langka". ${ }^{17}$

Dari definisi di atas dapat disimpulkan ada satu unsur yang penting dalam studi ekonomi yaitu unsur kekayaan, dimana kunci sukses di dalam pemenuhan tingkatan kebutuhan manusia adalah kekayaan dan sumber-sumbernya. Dengan kekayaan maka kebutuhan akan terpenuhi, dimana semakin kaya seseorang maka akan semakin tinggi kemampuannya untuk memenuhi semua ke butuhannya.

\section{b. Tingkat ekonomi keluarga}

Tingkat ekonomi keluarga antara satu dengan yang lain berbeda, dan dapat dibagi menjadi tiga tingkatan yaitu tinggi, menengah dan rendah. ${ }^{18}$ Menurut Coleman dan Cressey, "Klasifikasi status sosial ekonomi dibagi menjadi sosial ekonomi atas, menegah dan bawah". ${ }^{19}$

\footnotetext{
13 “Arti kata ekonomi - Kamus Besar Bahasa Indonesia (KBBI) Online,” diakses 11 Juni 2021

${ }^{14}$ Rosyidi, Mikroekonomi. Teori Permintaan (Jakarta: Erlangga, 2009), 7.

${ }^{15}$ Richard G Lipsey dan Peter O Steiner, Pengantar Ilmu Ekonomi I Edisi Keenam (Jakarta: Rineka Cipta, 1991), 9.

16 “Pengertian Ilmu Ekonomi: Konsep, Manfaat, dan Ruang Lingkupnya," diakses 11 Juni 2021

17 "Pengertian Ekonomi Syariah Menurut Para Ahli TipsSerbaSerbi," diakses 11 Juni 2021

${ }^{18}$ Hadi Sadikin, Tata Laksana Rumah Tangga (Jakarta: FIP. IKIP, 1975), 20.

${ }^{19}$ Wijianto dan Ika Farida Ulfa, "Pengaruh Status Sosial dan Kondisi Ekonomi Keluarga terhadap Motivasi Bekerja bagi Remaja Awal (Usia 12-16 Tahun) di Kabupaten Ponorogo," Al Tijarah 2, no. 2 (31 Desember 2016): 194
} 
Pengaruh Ekonomi Terhadap Perceraian di Kabupaten Pacitan | Mansur Azis

1) Tingkat ekonomi keluarga tinggi

Menurut Sitorus, "Kedudukan seseorang dalam masyarakat yang di ukur berdasarkan tingkat harta kekayaan yang di miliki, melebihi harta kekayaan masyarakat pada umumnya, dan mereka mampu memenuhi kebutuhan hidupnya dengan baik". ${ }^{20}$

2) Tingkat ekonomi keluarga menengah

Kelas menengah diidentikkan oleh kaum professional, pegawai pemerintah, karyawan, dan para bisnis UKM. Kelompok keluarga ini biasanya mereka sedang-sedang saja dalam kemampuan memenuhi kebutuhannya.

3) Tingkat ekonomi keluarga bawah.

Sumardi, mengemukakan bahwa kelas bawah yaitu“Golongan yang kebutuhan pokoknya lebih besar dari pada pendapatan atau penerimaan imbalan kerja yang di peroleh". ${ }^{21}$ Kelompok ini biasanya adalah kuli tani serabutan, pembantu, dan pengangguran. Kelompok ini termasuk dalam kategori fakir dan miskin kerena mereka mendapatkan imbalan dari pekerjaannya lebih sedikit dibanding dengan kebutuhannya.

\section{c. Indikator tingkat ekonomi keluarga.}

. Menurut Abdulsyani ada beberapa indikator yang sering digunakan untuk mengukur status tingkat ekonomi yaitu: ${ }^{22}$

\section{1) Pendidikan}

\section{Dalam UU SISDIKNAS No. 20 tahun 2003: Pendidikan yaitu} upaya dalam mengembangkan potensi dirinya untuk memiliki kepribadian, keagamaan, pengendalian diri, kecerdasan, dan akhlak mulia.

\section{2) Pekerjaan}

Mulyanto menjelaskan bahwa, manusia bekerja untuk memenuhi kebutuhan primer dan sekundenya. ${ }^{23}$

\section{3) Pendapatan}

Pendapatan adalah imbalan yang diterima oleh seseorang dalam bentuk gaji, upah sewa, bunga, laba dan lain sebagainya.

\footnotetext{
${ }^{20}$ Wijianto dan Ulfa, 195-195.

${ }^{21}$ Mulyanto Sumardi, Kemiskinan dan Kebutuhan Pokok. (Jakarta: CV Rajawali Press, 1982), 80-

${ }^{22}$ Abdulsyani, Sosiologi Skematik, Teori dan Terapan (Jakarta: Bumi Aksara, 2012), 73.

${ }^{23}$ Sumardi, Kemiskinan dan Kebutuhan Pokok., 2.
} 81. 
Pengaruh Ekonomi Terhadap Perceraian di Kabupaten Pacitan | Mansur Azis

Dari uraian di atas peneliti merinci indikator tingkat ekonomi keluarga menjadi tiga bagian:

\section{1) Tingkat Pendidikan}

Tingkat pendidikan adalah tahapan pendidikan yang ditetapkan berdasarkan tingkat perkembangan peserta didik, tujuan yang akan dicapai, dan kemampuan yang dikembangkan Jadi yang dimaksud dalam hal ini adalah pendidikan formal atau akademis, Tingkat pendidikan di Indonesia meliputi:

a) Pendidikan Anak Usia Dini

Dalam Undang-undang Nomor 20 Tahun 2003, Pasal 1 Butir 14 tentang Sistem Pendidikan Nasional, Pendidikan anak usia dini (PAUD) adalah suatu upaya pembinaan yang ditujukan bagi anak sejak lahir sampai dengan usia enam tahun yang dilakukan melalui pemberian rangsangan pendidikan untuk membantu pertumbuhan dan perkembangan jasmani dan rohani agar anak memiliki kesiapan dalam memasuki pendidikan lebih lanjut. Dalam hal ini dapat berbentuk sekolah playgroup atau taman kanak-kanak.

b) Pendidikan Dasar

Dalam Undang-undang Nomor 20 Tahun 2003, Pasal 17 ayat 2 disebutkan "Pendidikan dasar berbentuk Sekolah Dasar (SD) dan Madrasah Ibtidaiyah (MI) atau bentuk lainyang sederajat serta Sekolah Menengah Pertama (SMP) dan Madrasah Tsanawiyah (MTs), ataubentuk lain yang sederajat".

Jadi pendidikan dasar merupakan jenjang pendidikan awal selama 9 (sembilan) tahun pertama masa sekolah anak-anak yang melandasi jenjang pendidikan menengah.

c) Pendidikan Menengah

Dalam Undang-undang Nomor 20 Tahun 2003, Pasal 18 ayat 1 disebutkan bahwa "Pendidikan menengah merupakan lanjutan pendidikan dasar". Dan pada ayat 3 di sebutkan bahwa "Pendidikan menengah berbentuk Sekolah Menengah Atas (SMA), Madrasah Aliyah (MA),Sekolah Menengah Kejuruan (SMK), dan Madrasah Aliyah Kejuruan (MAK), atau bentuk lain yang sederajat". 
Pengaruh Ekonomi Terhadap Perceraian di Kabupaten Pacitan | Mansur Azis Maka Pendidikan menengah merupakan jenjang pendidikan lanjutan pendidikan dasar yang harus dilaksanakan minimal 3 tahun,

d) Pendidikan Tinggi

Dalam Undang-undang Nomor 20 Tahun 2003, Pasal 19 ayat 1 disebutkan bahwa "Pendidikan tinggi merupakan jenjang pendidikan setelah pendidikan menengah yang mencakupprogram pendidikan diploma, sarjana, magister, spesialis, dan doktor yang diselenggarakan oleh perguruan tinggi”.

\section{2) Jenis Pekerjaan}

Pekerjaan adalah suatu kegiatan yang wajib dilakukan oleh setiap orang untuk memenuhi berbagai macam kebutuhan hidupnya. Jenis pekerjaan merupakan penggolongan pekerjaan berdasarkan tugas dan tanggung jawab, kondisi pekerjaan, hubungan pekerjaan.

Menurut permenker No.1 Tahun 2014 pasal 1 ayat 19 "Jenis pekerjaan/jabatan adalah macam pekerjaan yang di lakukan oleh seseorang atau ditugaskan kepada seseorang yang sedang bekerja atau ditugaskan kepada seseorang yang sedang bekarja atau sementara". Adapan jenis pekerjaan yaitu:

a) Tenaga professional, teknisi dan yang sejenis.

b) Tenaga kepemimpinan dan tatalaksana.

c) Tenaga tata usaha dan yang sejenis

d) Tenaga usaha penjualan.

e) Tenaga usaha jasa.

f) Tenaga usaha pertanian, kehutanan, perikanan.

g) Tenaga produksi, operataor dll.

Sedangkan menurut Kenneth D. Hopkin dan Julian C. Stanley dalam Zulfiah $^{24}$. Jenis pekerjaan adalah:

a) Professional dan pemilik

b) Pegawai

c) Tata usaha

d) Pedagang

${ }^{24}$ Lilis Nur Chotimah, Hety Mustika Ani, dan Joko Widodo, "PENGARUH STATUS SOSIAL EKONOMI ORANG TUA TERHADAP PRESTASI BELAJAR SISWA (Studi Kasus Siswa Kelas VIII SMP Negeri 1 Jember Tahun Ajaran 2016/2017)," JURNAL PENDIDIKAN EKONOMI: Jurnal Ilmiah IImu Pendidikan, Ilmu Ekonomi dan Ilmu Sosial 11, no. 1 (18 Juli 2017): 75 
Pengaruh Ekonomi Terhadap Perceraian di Kabupaten Pacitan | Mansur Azis

e) Operator, seni trampil

f) Buruh

Dalam penelitaian ini peneliti membadakan jenis pekerjaan menjadi tiga yaitu:

a) Jenis pekerjaan golongan atas yaitu:

(1) Pengusaha

(2) Professional/pemilik perusahaan

(3) Pejabat pemerintah

(4) Petani profesional

b) Jenis pekerjaan menengah

(1) Wiraswasta

(2) Pegawai swasta

(3) Pedagang

(4) Teknisi dll.

c) Jenis pekerjaan bawah

(1) Buruh.

(2) Tukang.

(3) Asisten rumah tangga

(4) Penganguran.

(5) Petani non professional

(6) IRT

\section{3) Pendapatan}

Pendapatan dalam ilmu ekonomi didefinisikan sebagai hasil berupa uang atau materi lainnya yang dicapai dari penggunaan kekayaan atau jasa manusia bebas. Sedangkan pendapatan rumah tangga adalah total pendapatan dari setiap anggota rumah tangga dalam bentuk uang atau natura yang diperoleh baik sebagai gaji atau upah usaha rumah tangga atau sumber lain. Kondisi seseorang dapat diukur dengan menggunakan konsep pendapatan yang menunjukkan jumlah seluruh uang yang diterima oleh seseorang atau rumah tangga selama jangka waktu tertentu ${ }^{25}$ (USU, 2010). Pendapatan adalah imbalan yang diterima oleh seseorang dalam bentuk gaji, upah sewa, bunga, laba dan lain sebagainya.

${ }^{25}$ I B. Wirahaji, D. M. Priyantha Wedagama, dan P. Alit Suthanaya, "Analisis Pengaruh Pendapatan Terhadap Kepemilikan Mobil dan Sepeda Motor Pada Rumah Tagga Di Sepanjang Koridor Trayek Trans Sarbagita," Jurnal Spektran, 1 Januari 1970 
Pengaruh Ekonomi Terhadap Perceraian di Kabupaten Pacitan | Mansur Azis

Menurut Russel Swanburg pendapatan adalah pemasukan dari penjualan produk dan pelayanan. ${ }^{26}$ Definisi lain dari pendapatan adalah jumlah penghasilan yang diperoleh dari hasil pekerjaan dan biasanya pendapatan seseorang dihitung setiap tahun atau setiap bulan.

Dengan demikian pendapatan merupakan gambaran terhadap posisi ekonomi keluarga dalam masyarakat. Pendapatan dapat dihitung melalui tiga cara yaitu: ${ }^{27}$

a) Cara Pengeluaran. Cara ini pendapatan dihitung dengan menjumlahkan nilai pengeluaran/perbelanjaan ke atas barang-barang dan jasa.

b) Cara Produksi. Cara ini pendapatan dihitung dengan menjumlahkan nilai barang dan jasa yang dihasilkan.

c) Cara Pendapatan. Dalam penghitungan ini pendapatan diperoleh dengan menjumlahkan seluruh pendapatan yang diterima.

Secara garis besar pendapatan digolongkan menjadi tiga golongan, yaitu. $^{28}$

a) Gaji dan Upah. Imbalan yang diperoleh setelah orang tersebut melakukan pekerjaan untuk orang lain yang diberikan dalam waktu satu hari, satu minggu maupun satu bulan.

b) Pendapatan dari Usaha Sendiri. Merupakan nilai total dari hasil produksi yang dikurangi dengan biaya-biaya yang dibayar danusaha ini merupakan usaha milik sendiri atau keluarga dan tenaga kerja berasal dari anggota keluarga sendiri, nilai sewa kapital milik sendiri dan semua biaya ini biasanya tidak diperhitungkan.

c) Pendapatan dari Usaha Lain. Pendapatan yang diperoleh tanpa mencurahkan tenaga kerja, dan ini biasanya merupakan pendapatan sampingan antara lain, pendapatan dari hasil menyewakan asset yang dimiliki seperti rumah, ternak dan barang, bunga dari uang, sumbangan dari pihak lain, pendapatan dari pensiun, dan lain-lain.

Sedangkan pendapatan menurut perolehannya dibedakan menjadi: ${ }^{29}$

a) Pendapatan kotor yaitu pendapatan yang diperoleh sebelum dikurangi pengeluaran dan biaya-biaya.

${ }^{26}$ Russel C Swanburg dan Ester Monica, Pengantar kepemimpinan \& manajemen keperawatan untuk perawat klinis (Jakarta: Penerbit Buku Kedokteran, 2000).

${ }^{27}$ Sadono Sukirno, Makro Ekonomi Teori Pengantar(Jakarta: Raja Grafindo Perkasa, 2000), 66.

${ }^{28}$ M. Suparmoko, Pengantar Ekonomi Makro (Jakarta: BPFE, 2000), 77.

${ }^{29}$ M. Tohar, Membuka Usaha Kecil(Yogyakarta: Kanisius, 2003), 22. 
Pengaruh Ekonomi Terhadap Perceraian di Kabupaten Pacitan | Mansur Azis

b) Pendapatan bersih yaitu pendapatan yang diperoleh sesudah dikurangi pengeluaran dan biaya-biaya.

Sedangkan pendapatan menurut bentuknya dibedakan menjadi:

a) Pendapatan berupa uang adalah segala penghasilan yang sifatnya reguler dan yang diterima biasanya sebagai balas jasa, sumber utamanya berupa gaji, upah, bangunan, pendapatan bersih dari usaha sendiri dan pendapatan dari penjualan seperti: hasil sewa, jaminan sosial, premi asuransi.

b) Pendapatan berupa barang adalah segala penghasilan yang sifatnya reguler dan biasanya tidak berbentuk balas jasa dan diterima dalam bentuk barang.

Menurut Yudhohusodo, ingkat pendapatan seseorang dapat digolongkan dalam 4 golongan yaitu: ${ }^{30}$

a) Golongan yang berpenghasilan rendah (low income group).

b) Golongan berpenghasilan sedang (moderate income group).

c) Golongan berpenghasilan menengah (midle income group).

d) Golongan yang berpenghasilan tinggi (high income group)

\section{PEMBAHASAN}

Hasil uji statistik pengaruh ekonomi keluarga (Pendidikan, Jenis pekerjaan dan pendapatan) terhadap perceraian di Kabupaten Pacitan dapat disajikan dalam tabel berikut:

\section{Tabel. 4. 1}

\section{Rekapitulasi Hasil Pengujian Statistik}

\begin{tabular}{|c|c|c|c|}
\hline & Uji Regresi & Uji T & Keterangan \\
\hline $\begin{array}{l}\text { Pendidikan } \\
\text { berpengaruh } \\
\text { signifikan terhadap } \\
\text { perceraian di } \\
\text { Kabupaten Pacitan }\end{array}$ & $\begin{array}{l}\text { Koefisien } \\
\text { regresi variabel } \\
\text { pendidikan } \\
\text { sebesar } 1,342 \\
\text { yang artinya } \\
\text { terjadi hubungan }\end{array}$ & $\begin{array}{l}\text { Variabel pendidikan } \\
\text { memiliki nilai } \mathrm{t} \\
\text { hitung sebesar } 2,693 \\
>\mathrm{t} \text { tabel sebesar } \\
1,987 \text { dengan nilai } \\
\text { signifikan } 0,008<\end{array}$ & $\begin{array}{l}\text { Pendidikan berpengaruh } \\
\text { signifikan terhadap } \\
\text { perceraian di Kabupaten } \\
\text { Pacitan }\end{array}$ \\
\hline
\end{tabular}

${ }^{30}$ Siswono Yudohusodo, Transmigrasi: kebutuhan negara kepulauan berpenduduk heterogen dengan persebaran yang timpang, Cet. 1 (Jakarta: Jurnalindo Aksara Grafika, 1998), 86. 
Pengaruh Ekonomi Terhadap Perceraian di Kabupaten Pacitan | Mansur Azis

\begin{tabular}{|c|c|c|c|}
\hline & $\begin{array}{l}\text { positif antara } \\
\text { pendidikan dan } \\
\text { perceraian di } \\
\text { Kabupaten } \\
\text { Pacitan }\end{array}$ & $\begin{array}{lll}0,05 \quad \text { maka } & \mathrm{H}_{0} 1 \\
\text { ditolak dan } & \mathrm{H}_{\mathrm{a}} 1 \\
\text { diterima } & \end{array}$ & \\
\hline $\begin{array}{l}\text { Jenis pekerjaan } \\
\text { berpengaruh } \\
\text { signifikan terhadap } \\
\text { perceraian di } \\
\text { Kabupaten Pacitan }\end{array}$ & $\begin{array}{l}\text { Koefisien jenis } \\
\text { pekerjaan } \\
\text { sebesar } 0,200 \\
\text { yang artinya } \\
\text { terjadi hubungan } \\
\text { positif antara } \\
\text { jenis pekerjaan } \\
\text { dengan } \\
\text { perceraian di } \\
\text { Kabupaten } \\
\text { Pacitan }\end{array}$ & 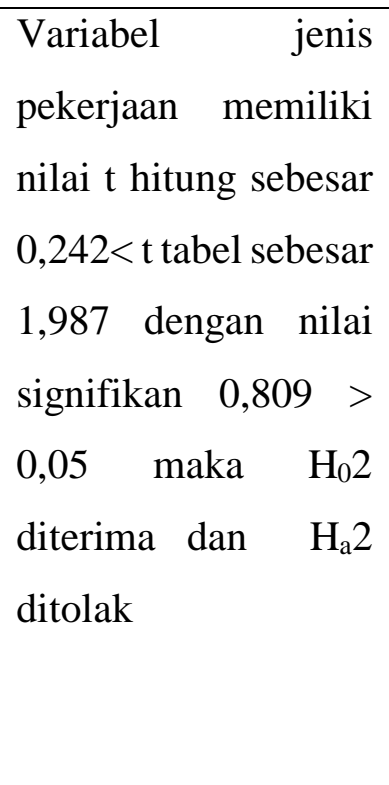 & $\begin{array}{l}\text { Jenis pekerjaan tidak } \\
\text { berpengaruh terhadap } \\
\text { perceraian di Kabupaten } \\
\text { Pacitan }\end{array}$ \\
\hline $\begin{array}{l}\text { Pendapatan } \\
\text { berpengaruh } \\
\text { signifikan terhadap } \\
\text { perceraian di } \\
\text { Kabupaten Pacitan }\end{array}$ & $\begin{array}{l}\text { Koefisien } \\
\text { regresi variabel } \\
\text { jumlah } \\
\text { komisaris } \\
\text { independen } \\
\text { sebesar } 2,309 \\
\text { yang artinya } \\
\text { terjadi hubungan } \\
\text { positif antara. }\end{array}$ & $\begin{array}{l}\text { Variabel jumlah } \\
\text { komisaris } \\
\text { independen memiliki } \\
\text { nilai t hitung sebesar } \\
\begin{array}{llr}2,678> & \text { tabel } \\
\text { sebesar } & & -1,987 \\
\text { dengan } & & \text { nilai } \\
\text { signifikan } & 0,009 & > \\
0,05 \quad \text { maka } & \mathrm{H}_{0} 3 \\
\text { ditolak dan } & \mathrm{H}_{\mathrm{a}} \\
\text { diterima }\end{array}\end{array}$ & $\begin{array}{l}\text { Pendapatan berpengaruh } \\
\text { signifikan terhadap } \\
\text { perceraian di Kabupaten } \\
\text { Pacitan }\end{array}$ \\
\hline $\begin{array}{l}\text { Pendidikan, Jenis } \\
\text { pekerjaan dan } \\
\text { pendapatan } \\
\text { (ekonomi keluarga) } \\
\text { berpengaruh } \\
\text { signifikan terhadap }\end{array}$ & \multicolumn{3}{|c|}{$\begin{array}{l}\text { Nilai } \mathrm{F} \text { hitung sebesar } 18,441>\mathrm{F} \text { tabel sebesar } 2,71 \text { dan nilai } \\
\text { signifikan } 0,000<0,05 \text { maka Ho4 ditolak dan Ha4 diterima. Artinya } \\
\text { ekonomi (Pendidikan, Jenis pekerjaan dan pendapatan) berpengaruh } \\
\text { signifikan terhadap perceraian di Kabupaten Pacitan. }\end{array}$} \\
\hline
\end{tabular}




\begin{tabular}{|l|l|}
\hline $\begin{array}{l}\text { perceraian di } \\
\text { Kabupaten Pacitan. }\end{array}$ & \\
\hline Koefisien & $\begin{array}{l}\text { Nilai R square 0,383 yang menunjukkan bahwa Pendidikan, Jenis } \\
\text { determinasi }\left(\mathrm{R}^{2}\right)\end{array}$ \\
$\begin{array}{l}\text { pekerjaan dan pendapatan mampu mempengaruhi sebesar 38,3 } \\
\text { dipengaruhi oleh variabel lain di luar model penelitian ini }\end{array}$ \\
\hline
\end{tabular}

\section{Pengaruh pendidikan terhadap perceraian di Kabupaten Pacitan.}

Hasil analisis regresi variabel pendidikan memiliki koefisien regresi bernilai positif sebesar 1,342. Artinya semakin banyak orang yang berpendidikan rendah maka semakin banyak percaraian di Kabupaten Pacitan. Sedangkan hasil uji hipotesis variabel pendidikan memiliki nilai t hitung sebesar 2,693>t tabel sebesar 1,987 dengan nilai signifikan $0,008<0,05$ maka $\mathrm{H}_{0} 1$ ditolak dan $\mathrm{H}_{\mathrm{a}} 1$ diterima. Hasil tersebut menunjukkan bahwa tingkat pendidikan berpengaruh terhadap perceraian di Kabupaten Pacitan.

Dari hasil skor kuisioner yang peneliti sebar di peroleh persentase jawaban responden seperti keterangan pada tabel 04.03 bahwa responden yang melakukan perceraian dengan Pendidikan SD sebanyak 32 atau $34 \%$, Pendidikan SMP 44 orang atau 47\%, Pendidikan SMA 12 Orang atau 13\%, dan Pendidikan perguruan tinggi sebanyak 5 orang atau 6\%. Yang artinya bahwa semakin rendah Pendidikan seseorang maka semakin tinggi kecenderunganya untuk melakukan perceraian, begitu juga sebaliknya semakin tinggi tingkat Pendidikan seseorang maka semakin rendak untuk melakukan perceraian.

Hasil hipotesisnya adalah:

\section{H1 : Pendidikan berpengaruh signifikan terhadap perceraian di Kabupaten Pacitan}

Berdasarkan perspektif Islamic accountability theory, latar belakang pendidikan anggota keluarga yang tinggi dianggap memiliki pengetahuan yang lebih baik sehingga dapat melakukan pertanggungjawaban sosial secara optimal. Anggota keluarga yang memiliki pendidikan tinggi dianggap memiliki kualitas keahlian yang lebih baik dalam bidang ilmu pengetahuan sehingga dapat mengatasi semua masalah yang ada di keluarga. Menurut sebuah penelitian, Pendidikan seseorang merupakan salah satu faktor perceraian. Dimana dengan tingginya tingkat pendidikan seseorang akan mampu berfikir lebih matang dan lebih kritis dalam menyikapi berbagai 
Pengaruh Ekonomi Terhadap Perceraian di Kabupaten Pacitan | Mansur Azis masalah yang ada. walaupuan ada juga kasus perceraian yang dilakukan oleh Pendidikan atas namun haya kecil prosentasinya, tetapi tidak boh juga di abaikan,

Peneliti juga menggali informasi dengan mewawancarai salah satu responden, dan ia mengatakan "awalnya pernikahan saya dengan istri berjalan harmonis, namun sejak bulan Maret 2019 rumah tangga antara saya dengan istri mulai goyah serta sering terjadi perselisihan dan pertengkaran yang disebabkan karena istri sudah tidak mau lagi tinggal bersama dirumah orang tua saya dengan alasan tidak betah dan tidak bisa beradaptasi dengan lingkungan sekitar sedangkan saya juga tidak bisa apabila harus tinggal menetap dirumah orang tua istri saya dikarenakan saya saat ini menjadi satu-satunya harapan bagi orang tua saya untuk menemani dan merawatnya" dan peneliti juga mewawancarai tentang Pendidikan terahirnya, ia mengatakan, " saya dan istri saya hanya lulusan SMP". 31

Dari hasil wawancara diatas bisa di pahami bahwa salah satu penyebab retaknya hubungan suami isti karena tidak bisa saling memahami, tidak ada tanggungjawab dalam melakukan perannya sebagai suami maupun istri, ini dikarenakan pemahaman/pengetahuan untuk menjadi suami istri masih rendah, karena responden ini dan istrinya haya berpendidikan menegah kebawah.

Selan responden diatas penelitu juga mewawancarai responden yang lain ia mengatakan kenapa harus bercerai "perceraian saya disebabkan karena istrisaya sudah tidak mau untuk diajak berhubungan suami isteri lagi, dan istri saya memutuskan untuk meninggalkan saya pulang kembali kerumah orang tuanya sehingga hal tersebut membuat saya merasa sangat menderita lahir batin dan membuat saya merasa sudah tidak dihargai lagi sebagai seorang suami atau kepala rumah tangga serta membuat saya merasa sudah tidak diharapkan keberadaanya lagi oleh dia (istri)". ${ }^{32}$ Dan Ketika saya bertanya tentang Pendidikan terahir responden dan istrinya ia mengatakan" saya hanya lulusan SMP dan istri hanya tamatan SD". ${ }^{33}$

Dari hasil wawancara diatas dapat mejelaskan bahwa Pendidikan sangat berpengaruh secara signifikan terhadap perceraian di Kabupaten Pacitan. Karena Pendidikan itu penting dalam membentuk dan membina seseorang utuk menjadi manusia yang baik seperti yang di katakana oleh Ki Hadjar Dewantoro mengatakan tujuan pendidikan adalah mendidik anak agar menjadi manusia yang sempurna

\footnotetext{
${ }^{31}$ Juri Bin Daeman. Wawancara

${ }^{32}$ Enggel Derano. Wawancara

${ }^{33}$ Enggel Derano. Wawancara
} 
Pengaruh Ekonomi Terhadap Perceraian di Kabupaten Pacitan | Mansur Azis hidupnya, yaitu kehidupan dan penghidupan manusia yang selaras dengan alamnya (kodratnya) dan masyarakatnya. ${ }^{34}$

Tujuan pendidikan nasional yang tertuang dalam UU No. 20 Tahun 2003 Tentang Sistem Pendidikan Nasional Pasal 3 berbunyi,"pendidikan nasional bertujuan untuk berkembangnya potensi peserta didik agar menjadi manusia yang beriman dan bertakwa kepada Tuhan Yang Maha Esa, berakhlak mulia, sehat, berilmu, cakap, kreatif, mandiri, dan menjadi warga negara yang demokratis serta bertanggung jawab". 35

Penelitian yang mendukung penelitian ini yaitu penelitian yang di kakuan oleh Hasto, menyatakan bahwa, sebanyak 11 orang atau 73,33\% yang melakukan perceraian mereka berpendidikan rendah, sedangkan sisanya sebanyak 4 orang atau sekitar 26,67\% yang melakukan perceraan dari responden yang berpendidikan tinggi. ${ }^{36}$ Penelitian yang dilakukan oleh Oktary menyatakan bahwa, tingkat pendidikan berpengaruh terhadap cerai gugat. Mayoritas perempuan yang melakukan perceraian adalah mereka yang mempunyai pendidikan tinggi karena mereka mengangap mampu untuk mencari kebutuhannya sendiri. ${ }^{37}$ Penelitian yang dilakukan oleh Rokhmadi menyatakan bahwa masyarakat yang tingkat pendidikan dasar dan menengah akan cenderung lebih mudah melakukan perceraian, sedangkan masyarakat yang tingkat pendidikan tinggi akan cenderung lebih mampu mengendalikan diri dari melakukan perceraian, karena variabel tidak dalam persamaan (variables not in the equation) skornya 5,738 dengan taraf signifikansi 0,017 lebih kecil dari $0,05(0,017<0,05) .{ }^{38}$ Selanjutnya penelitian yang dilakukan oleh Nasir dan hasil penelitiannya menyatakan bahwa pasangan dengan tingkat sekolah menengah umum paling banyak mengalami perceraian. ${ }^{39}$

\footnotetext{
${ }^{34}$ Suwarno, Pengantar Umum Pendidikan (Yogyakarta: Rineka Cipta, 1992), 52.

35 Angga Tanama Putra, "MAKALAH TUJUAN PENDIDIKAN," diakses 11 Juni 2021, https://www.academia.edu/4563266/MAKALAH_TUJUAN_PENDIDIKAN.

36 NUR MUHAMMAD HASTO NN, "PENGARUH TINGKAT PENDIDIKAN TERHADAP PERCERAIAN (Studi Pada Masyarakat Kecamatan Raja Basa Kota Bandar Lampung Tahun 2009)," Digital Libary, 25 Januari 2012

37 Yusni Maulida, Lapeti Sari, dan Novie Oktary, “Analisis Faktor-faktor yang Mempengaruhi Tingkat Cerai Gugat di Kota Pekanbaru” (Journal:eArticle, Universitas Riau, 2014), 17

38 Rokhmadi Rokhmadi, "PENGARUH JENIS PEKERJAAN DAN TINGKAT PENDIDIKAN TERHADAP PERCERAIAN DI PENGADILAN AGAMA SEMARANG TAHUN 2015,”At-Taqaddum 10, no. 2 (31 Desember 2018): 109

${ }^{39}$ Badruddin Nasir, "Faktor-Faktor Yang Mempengaruhi Perceraian Di Kecamatan Sungai Kunjang Kota Samarinda,” Psikostudia : Jurnal Psikologi 1, no. 1 (15 Juni 2012): 31
} 
Pengaruh Ekonomi Terhadap Perceraian di Kabupaten Pacitan | Mansur Azis

\section{Pengaruh jenis pekerjaan terhadap perceraian di Kabupaten Pacitan.}

Hasil analisis regresi variabel jenis pekarjaan memiliki koefisien regresi bernila positif sebesar 0,200. Artinya semakin banyak orang yang memiliki jenis pekarjaan menegah kebawah (IRT/Buruh/Kuli/Tani) maka semakin maka semakin banyak perceraian di Pacitan. Sedangkan hasil uji hipotesis variabel jumlah komisaris independen menghasilkan nilai Variabel jenis pekerjaan memiliki nilai $t$ hitung sebesar 0,242<t tabel sebesar 1,987 dengan nilai signifikan 0,809>0,05 maka $\mathrm{H}_{0} 2$ diterima dan $\mathrm{H}_{\mathrm{a}} 2$ ditolak

Hasil tersebut menunjukkan bahwa Jenis pekerjaan tidak berpengaruh terhadap perceraian di Kabupaten. Karena berdasarkan hasil pengumpulan data terlihat jenis pekerjaan yang baik juga masih melakukan perceraian kita bisa lihat data pada tabel 04.04 yaitu responden dengan jenis pekerjaan IRT/Penganguran yang melakukan perceraian sebanyak 39 orang atau, 42\%, responden dengan jenis pekarjaan buruh/kuli/petani perceraian sebanyak 40 orang atau $43 \%$ responden dengan jenis pekerjaan karyawan, swasta, wiraswasta sebanyak 8 orang atau 9\%, dan responden dengan jenis pekerjaan PNS, Pejabat, pengusaha sebanyak 6 orang atau $6 \%$.

Hasil hipotesisnya adalah;

\section{H2 : Jenis pekerjaan tidak berpengaruh signifikan terhadap perceraian di Kabupaten Pacitan}

Menurut Rokhmadi jenis pekerjaan seseorang akan berpengaruh positif terhadap sikap dan tingkah laku dalam berumah tangga, bermasyarakat maupun bernegara. Atas dasar itulah, kualitas jenis pekerjaan sangat berpengaruh terhadap kemajuan dan kemakmuran masyarakat dalam membentuk keluarga yang bahagia, sejahtera lahir dan batin, sehingga dapat mengurangi pemicu tindakan kekejaman jasmani dan kekejaman rohani dalam masyarakat. ${ }^{40}$ Namun kenyatanya hal ini tidak terjadi pada masyarakat Pacitan, karena banyak juga perceraian yang di lakukan oleh masyarakat yang mempunyai tingkat/jenis pekerjaan yang baik diantaranya PNS/Pejabat dll.

Seperti yang di ungkapkan oleh salah satu responden dengan ia mengatakan" semula rumah tangga saya dengan suami berjalan harmonis, namun sejak awal bulan November 2017 rumah tangga saya dengan suami mulai goyah serta sering terjadi perselisihan dan pertengkaran disebabkan karena didalam kepengurusan rumah

${ }^{40}$ Rokhmadi, "PENGARUH JENIS PEKERJAAN DAN TINGKAT PENDIDIKAN TERHADAP PERCERAIAN DI PENGADILAN AGAMA SEMARANG TAHUN 2015.” 
Pengaruh Ekonomi Terhadap Perceraian di Kabupaten Pacitan | Mansur Azis tangga maupun didalam segala hal suami saya selalu ingin menang sendiri dan menuntut untuk dituruti apa yang ia inginkan, dan melakukan kekerasan fisik dan verbal, seharusnya belau mendidik saya kalua saya salah, dan beliau juga seorang pejabat kelurahan yang harus jadi panutan.

Penelitian yang selaras denagan penelitian ini namun hasilnya bervariasi diantaranya yaitu penelitian yang dilakukan oleh Rokhmadi menunjukkan bahwa, perceraian masyarakat cenderung lebih mudah dilakukan oleh masyarakat yang memiliki latar belakang jenis pekerjaan Non-ASN, dibandingkan dengan yang memiliki latar belakang pekerjaan PNS, dengan skor 6,512 dengan taraf signifikansi 0,011 lebih kecil dari $0,05(0,011<0,05) .{ }^{41}$ Penelitian yang dilakukan Nasir menunjukkan bahwa faktor perceraian jika dilihat dari pekerjaan, informan yang banyak mengalami perceraian itu ialah informan yang bekerja sebagai buruh. Hal ini dapat dikarenakan faktor pendapatan atau penghasilan dari pekerjaan mereka dalam memenuhi kebutuhan sehari-hari tidak dapat terpenuhi. ${ }^{42}$

Sedangkan penelitian yang mendukung dengan penelitian ini adalah penelitian yang dilakukan oleh Eli karlina menunjukkan bahwa pengaruh bekerja diluar negeri terhadap masyarakat di desa Cikedung tergolong rendah karena kurang dari 20 kasus.

\section{Pengaruh pendapatan terhadap perceraian di Kabupaten Pacitan.}

Hasil analisis regresi variabel pendapatan memiliki koefisien regresi bernilai positif sebesar 2,309. Artinya semakin banyak orang yang berpendapatan rendah maka semakin banyak percaraian di Kabupaten Pacitan. Sedangkan hasil uji hipotesis variabel pendapatan memiliki nilai t hitung sebesar 2,678 $>\mathrm{t}$ tabel sebesar $-1,987$ dengan nilai signifikan $0,009>0,05$ maka $\mathrm{H}_{0} 3$ ditolak dan $\mathrm{H}_{\mathrm{a}}$ diterima. Hasil tersebut menunjukkan bahwa pendapatan berpengaruh terhadap perceraian di Kabupaten Pacitan.

Dari hasil skor kuisioner yang peneliti sebar di peroleh persentase jawaban responden seperti keterangan pada tabel 04.05 bahwa responden yang melakukan perceraian dengan pendapatan $<1.000 .000$. sebanyak 36 atau $39 \%$, berpendapatan Rp 1.000 .000 - Rp 1.900 .000 sebanyak 41 orang atau 44\%, berpendapatan Rp 1.900.000 - Rp 3.000.000 sebanyak 14 orang atau 15\%, dan berpendapatan $>$ Rp.3.000.000 sebanyak 2 orang atau 2\%. Yang artinya bahwa semakin rendah

\footnotetext{
${ }^{41}$ Rokhmadi. Samarinda."

42 Nasir, "Faktor-Faktor Yang Mempengaruhi Perceraian Di Kecamatan Sungai Kunjang Kota
} Journal of Islamic Philanthropy and Disaster, Vol 1, No 1 (2021) | 20 
Pengaruh Ekonomi Terhadap Perceraian di Kabupaten Pacitan | Mansur Azis pendapatan seseorang maka semakin tinggi kecenderunganya untuk melakukan perceraian, begitu juga sebaliknya semakin tinggi pendapatannya seseorang maka semakin rendah untuk melakukan perceraian.

Hasil hipotesisnya adalah:

\section{H3 : Pendapatan berpengaruh signifikan terhadap perceraian di Kabupaten Pacitan}

Menurut Warfield, seperti yang dikutip Yuliyanto, mengemukakan bawa pendapatan adalah aktivitas normal entitas selama suatu periode yang menimbulkan arus masuk bruto. ${ }^{43}$ Pendapatan adalah imbalan yang diperoleh sebagai bentuk balas jasa, atau penghasilan yang bersumber pada usaha sendiri seperti, berniaga, bertani, berwirausaha, bekerja pada orang lain dan lain-lain. Diantara faktor-faktor peceraian adalah kestabilan kondisi ekonomi keluarga, dimana memang kestabilan kondisi ekonomi keluarga mempunyai kaitan yang sangat erat dengan kebahagiaan dalam keluarga, seperti halnya kelancaran usaha dan jumlah penghasilan mempunyai pengaruh akan lancarnya kehidupan rumah tangga. Dengan demikian jumlah penghasilan sering menjadi salah satu problem dalam kehidupan berumah tangga.

Seperti yang di ungkapkan salah satu responden ia mengatakan "semula rumah tangga saya dan suami berjalan harmonis, namun sejak bulan Juni 2018 rumah tangga saya mulai goyah serta sering terjadi perselisihan dan pertengkaran yang disebabkan karena suami saya jarang memberi nafkah dan apabila memberi nafkah jumlahnya sangat kurang sekali yaitu rata-rata sebesar Rp. 500.000,- (lima ratus ribu rupiah) setiap bulannya sehingga tidak cukup untuk memenuhi kebutuhan rumah tangga dan anak, hal tersebut membuat saya harus rela bekerja sendiri demi terpenuhinya kebutuhan rumah tangga dan serta anak bahkan untuk memenuhi kebutuhan anak kami selama ini terkadang masih dibantu oleh kakak saya". ${ }^{4}$

Dari hasil wawancara diatas jelas permasalahan yang mengakibatkan perceraian keluarga responden disebabkan oleh factor pendapatan yang rendah selain responden di atas peneliti juga mengali data kepada responden yang lain ia mengunkapkan “ perceraian keluarga saya disebabkan karena istri saya memiliki kebiasaan yang sangat buruk yaitu sering berhutang kepada tetangga dan ke warungwarung sekitar rumah tanpa sepengetahuan saya sebagai suami, sehingga sering kali

43 Ahmad Rudi Yulianto dan Bekti Syahputra, "PENGARUH TINGKAT PENDIDIKAN, PENDAPATAN, GENDER, DAN TEMPAT TINGGAL TERHADAP AKUNTANSI RUMAH TANGGA," MAKSIMUM 8, no. 2 (7 Mei 2019): 15

${ }^{44}$ Honesta. wawancara 
Pengaruh Ekonomi Terhadap Perceraian di Kabupaten Pacitan | Mansur Azis saya ditagih untuk melunasi hutang-hutang istri saya yang sudah menumpuk banyak, sedangkan saya hanya buruh harian yang pendapatanya tidak menentu dan akibat perbuatan itri saya tersebut membuat saya merasa malu dan tertekan bahkan ketika saya mencoba meminta penjelasan kepada dia tentang hutang tersebut istri saya tidak mau berterus terang justru ia merasa tersinggung sehingga selalu berujung pada pertengkaran". 45

Dari hasilwawan cara yang kedua tersebut juga menguatkan bahwa perceraian dapat di pengaruhi oleh pendapatan keluarga.

Penelitian yang mendukung penelitian ini adalah penelitian yang dilakukan oleh Kabalmay, pelaku perceraian di pada umumnya adalah pengangguran, yaitu, sebanyak 119 kasus, atau 30,27\% . petani dan nelayan hanya 13 kasus, atau 3,31\%. ${ }^{46}$ Penelitian yang dilakukan oleh Hakim, menunjukkan bahwa sebanyak 4905 kasus atau sekitar $88,38 \%$, di pengaruhi oleh faktor ekonomi dan sisanya sebanyak 11,62\% disebabkan oleh factor lain. Prosentasi perceraian karena faktor ekonomi menunjukan besarnya pengaruh ekonomi terhadap perceraian. ${ }^{47}$

\section{Pengaruh ekonomi (Pendidikan, jenis pekerjaan, dan pendapatan) terhadap perceraian di Kabupaten Pacitan.}

Hasil penelitian ini mendapatkan nilai F hitung sebesar 18,441 > F tabel sebesar 2,71 dan nilai signifikan 0,000 < 0,05 maka Ho4 ditolak dan Ha4 diterima. Artinya ekonomi (Pendidikan, Jenis pekerjaan dan pendapatan) berpengaruh signifikan terhadap perceraian di Kabupaten Pacitan..

Secara parsial jenis pekerjaan tidak berpengaruh signifikan terhadap perceraian di kabupaten Pacitan. Namun, secara simultan ketika terdapat sinergi antara banyaknya masyarakat yang berpendidikan rendah dan berpenghasilan rendah maka akan berpengaruh secara signifikan terhadap perceraian masyarakat di kabupaten Pacitan. Hal ini disebabkan semakin banyak jenis pekerjaan golongan bawah (kuli/buruh dll) maka akan semakin mempegaruhi pendapatan dan perekonomian masayarakat sehingga tidak mampu mengakomodasi dan memfasilitasi kepentingan setiap anggota keluarga untuk menciptakan kesejahtareaan aggota keluarga.

\footnotetext{
${ }^{45}$ Musani. Wawancara

${ }^{46}$ Kabalmay, "Kebutuhan Ekonomi dan Kaitannya Dengan Perceraian (Studi atas Cerai Gugat di Pengadilan Agama Ambon)," 60.

${ }^{47}$ Mohammad Ridwan Hakim, "Perceraian karena Faktor Ekonomi," t.t., 66.
} 
Pengaruh Ekonomi Terhadap Perceraian di Kabupaten Pacitan | Mansur Azis Berpengaruhnya uji F pada penelitian ini juga dikarenakan nilai $\mathrm{R}$ square yaitu sebesar 0,383 yang menunjukkan bahwa Pendidikan, Jenis pekerjaan dan pendapatan mampu mempengaruhi sebesar 38,3 perceraian di Kabupaten Pacitan dan sisanya sebesar 72,7\% dipengaruhi oleh variabel lain di luar model penelitian ini

\section{SIMPULAN}

Berdasarkan hasil penelitian dan pembahasan tentang ekonomi masyarakat yang di tinjau dari pendidikan, jenis pekerjaan dan pendapatan pengaruhnya erhadap perceraian di kabupaten Pacitan dapat disimpulkan sebagai berikut:

1. Berdasarkan hasil analisis regresi berganda menunjukkan bahwa pendidikan berpengaruh secara signifikan terhadap perceraian di kabupaten Pacitan dengan arah positif. Pendidikan berpengaruh terhadap perceraian di kabupaten Pacitan karena semakin banyak masyarakat yang berpendidikan rendah maka akan semakin banyak juga kasus perceraian di kabupaten Pacitan. Begitu juga sebaliknya semakin sedikit masayaraka yang berpendidikan rendah maka akan semakin sedikit perceraian di kabupaten Pacitan, hal ini dikarenakan apabila mereka mempunyai Pendidikan yang rendah maka mereka tidak mampu untuk mengelola kelurganya begitu juga sebaliknya apabila masyarakat berpendidikan tinggi maka meraka akan mampu mengelola rumah tangga lebih baik dengan pengetahuan yang dimilikinya.

2. Berdasarkan hasil analisis regresi berganda jenis pekerjaan tidak berpengaruh terhadap perceraian di kabupaten Pacitan. jenis pekerjaan tidak berpengaruh terhadap perceraian di kabupaten Pacitan. karena adanya variasi jenis pekerjaan yang memiliki pergerakan data jenis pekerjaan yang searah dan tidak searah perceraian di kabupaten pacitan yaitu jenis pekerjaan yang pada saat jenis pekerjaan dengan sekor nilai tinggi berkurang diiringi dengan turunnya kasus perceraian di Pacitan, dan pada saat jenis pekerjaan dengan sekor nilai tinggi berkurang juga tetapi kasus perceraian di kabupaten Pacitan cenderung naik.

3. Berdasarkan hasil analisis regresi berganda menunjukkan bahwa pendapatan berpengaruh singnifikan terhadap perceraian di kabupaten Pacitan. pendapatan berpengaruh singnifikan terhadap perceraian di kabupaten Pacitan karena semakin banyak masyarakat yang berpendapatan rendah maka akan semakin banyak juga kasus perceraian di kabupaten Pacitan. Begitu juga sebaliknya semakin sedikit masayaraka yang berpendapatan rendah maka akan semakin sedikit perceraian di kabupaten Pacitan, hal ini dikarenakan apabila mereka mempunyai pendapatan 
Pengaruh Ekonomi Terhadap Perceraian di Kabupaten Pacitan | Mansur Azis yang rendah maka mereka tidak mampu untuk mensejahterakan keluarganya begitu juga sebaliknya apabila masyarakat berpendapatan tinggi maka meraka akan mampu mensejahtarakan rumah tangganya lebih baik dengan penghasilan atau pendapatan yang dihasilkannya.

4. Berdasarkan hasil uji F menunjukkan bahwa ekonomi (Pendidikan, jenis pekerjaan, dan pendapatan) berpengaruh signifikan terhadap perceraian di kabupaten pacitan.. Dan untuk koefisien determinasi menunjukkan bahwa koefesien korelasi R square yaitu sebesar 0,383 yang menunjukkan bahwa Pendidikan, Jenis pekerjaan dan pendapatan mampu mempengaruhi sebesar 38,3 perceraian di Kabupaten Pacitan dan sisanya sebesar 72,7\% dipengaruhi oleh variabel lain di luar model penelitian ini. 


\section{Pengaruh Ekonomi Terhadap Perceraian di Kabupaten Pacitan | Mansur Azis}

DAFTAR PUSTAKA

"2 Hari Awal Ramadhan, PA Pacitan Tangani 30 Perkara Perceraian | Teras Jatim," 7 Mei 2019. https://www.terasjatim.com/2-hari-awal-ramadhan-pa-pacitan-tangani-30perkara-perceraian/.

Abdulsyani. Sosiologi Skematik, Teori dan Terapan. Jakarta: Bumi Aksara, 2012.

Abi Dawud. Sunan Abi Dawud. Vol. 2. Damsyik: Dar Ar-Risalah Al-Alamiyah, 2009.

“Arti kata ekonomi - Kamus Besar Bahasa Indonesia (KBBI) Online.” Diakses 11 Juni 2021. https://kbbi.web.id/ekonomi.

Chotimah, Lilis Nur, Hety Mustika Ani, dan Joko Widodo. "PENGARUH STATUS SOSIAL EKONOMI ORANG TUA TERHADAP PRESTASI BELAJAR SISWA (Studi Kasus Siswa Kelas VIII SMP Negeri 1 Jember Tahun Ajaran 2016/2017)." JURNAL PENDIDIKAN EKONOMI: Jurnal Ilmiah Ilmu Pendidikan, Ilmu Ekonomi dan Ilmu

1

Sosial 11, no. 1 (18 Juli 2017): 75. https://doi.org/10.19184/jpe.v11i1.5004.

DalamIslam.com. "Fiqih Pernikahan: Pengertian, Hukum dan Rukunnya," 8 Juni 2016. https://dalamislam.com/hukum-islam/pernikahan/fiqih-pernikahan.

Hakim, Mohammad Ridwan. "Perceraian karena Faktor Ekonomi," t.t., 85.

Kabalmay, Husin Anang. "Kebutuhan Ekonomi dan Kaitannya Dengan Perceraian (Studi atas Cerai Gugat di Pengadilan Agama Ambon)," no. 1 (2015): 21.

"Keluarga." Dalam Wikipedia bahasa Indonesia, ensiklopedia bebas, 24 Februari 2021. https://id.wikipedia.org/w/index.php?title=Keluarga\&oldid=18024813.

Lipsey, Richard G, dan Peter O Steiner. Pengantar Ilmu Ekonomi I Edisi Keenam. Jakarta: Rineka Cipta, 1991.

M. Suparmoko. Pengantar Ekonomi Makro. Jakarta: BPFE, 2000.

M. Tohar. Membuka Usaha Kecil. Yogyakarta: Kanisius, 2003.

Maribari, Zainuddi>n bin 'Abdul 'Azi>z al-. Fathul Mu'in bi Syarhi Quratul- 'Aini. Bairut: Dar Ibn Hazm, 2004.

Matondang, Armansyah. "Faktor-faktor yang Mengakibatkan Perceraian dalam Perkawinan." JPPUMA: Jurnal Ilmu Pemerintahan dan Sosial Politik UMA (Journal of Governance and Political Social UMA) 2, no. 2 (1 Desember 2014): 141-50. https://doi.org/10.31289/jppuma.v2i2.919.

Maulida, Yusni, Lapeti Sari, dan Novie Oktary. "Analisis Faktor-faktor yang Mempengaruhi Tingkat Cerai Gugat di Kota Pekanbaru.” Journal:eArticle, Universitas Riau, 2014. https://www.neliti.com/id/publications/33537/.

Nasir, Badruddin. "Faktor-Faktor Yang Mempengaruhi Perceraian Di Kecamatan Sungai Kunjang Kota Samarinda." Psikostudia : Jurnal Psikologi 1, no. 1 (15 Juni 2012): 31. https://doi.org/10.30872/psikostudia.v1i1.2172.

Newman, Barbara M., dan Philip R. Newman. Development through life: a psychosocial approach. 10e ed. Australia; Belmont, CA: Wadsworth/Cengage Learning, 2009.

NN, NUR MUHAMMAD HASTO. "PENGARUH TINGKAT PENDIDIKAN TERHADAP PERCERAIAN (Studi Pada Masyarakat Kecamatan Raja Basa Kota Bandar Lampung Tahun 2009)." Digital Libary, 25 Januari 2012. http://digilib.unila.ac.id/19698/.

"Pengertian Ekonomi Syariah Menurut Para Ahli | TipsSerbaSerbi." Diakses 11 Juni 2021. https://tipsserbaserbi.blogspot.com/2014/09/pengertian-ekonomi-islam-menurutpara.html.

"Pengertian Ilmu Ekonomi: Konsep, Manfaat, dan Ruang Lingkupnya." Diakses 11 Juni 2021. https://www.maxmanroe.com/vid/bisnis/pengertian-ilmu-ekonomi.html. 
Pengaruh Ekonomi Terhadap Perceraian di Kabupaten Pacitan | Mansur Azis "Perceraian di Pacitan Kian Mengkhawatirkan, Selama 2018 Ada 1.071 Janda Baru." Diakses 11 Juni 2021. https://halopacitan.com/read/perceraian-di-pacitan-kianmengkhawatirkan-selama-2018-ada-1-071-janda-baru.

Putra, Angga Tanama. "MAKALAH TUJUAN PENDIDIKAN." Diakses 11 Juni 2021. https://www.academia.edu/4563266/MAKALAH_TUJUAN_PENDIDIKAN.

“Qur'an Kemenag.” Diakses 11 Juni 2021. https://quran.kemenag.go.id/.

Rokhmadi, Rokhmadi. "PENGARUH JENIS PEKERJAAN DAN TINGKAT PENDIDIKAN TERHADAP PERCERAIAN DI PENGADILAN AGAMA SEMARANG TAHUN 2015.” At-Taqaddum 10, no. 2 (31 Desember 2018): 109. https://doi.org/10.21580/at.v10i2.2985.

Rosyidi. Mikroekonomi. Teori Permintaan. Jakarta: Erlangga, 2009.

Rudi Yulianto, Ahmad, dan Bekti Syahputra. "PENGARUH TINGKAT PENDIDIKAN, PENDAPATAN, GENDER, DAN TEMPAT TINGGAL TERHADAP AKUNTANSI RUMAH TANGGA." MAKSIMUM 8, no. 2 (7 Mei 2019): 77. https://doi.org/10.26714/mki.8.2.2018.77-85.

Sabiq, Sayyid. "Fiqh as Sunnah.pdf." Diakses 11 Juni 2021. https://docs.google.com/viewer?a=v\&pid=sites\&srcid=ZGVmYXVsdGRvbWFpbn xtZW50b3Jjb3VuY21sbGlicmFyeXxneDphN2Q2ZTkwZDYwNjc1NGE.

Sadikin, Hadi. Tata Laksana Rumah Tangga. Jakarta: FIP. IKIP, 1975.

Pacitan TRIP. "Sekilas Profil Kabupaten Pacitan," 9 November 2015. https://www.pacitantrip.com/profil-kabupaten-pacitan/.

Sukirno, Sadono. Makro Ekonomi Teori Pengantar. Jakarta: Raja Grafindo Perkasa, 2000.

Sumardi, Mulyanto. Kemiskinan dan Kebutuhan Pokok. Jakarta: CV Rajawali Press, 1982.

Suwarno. Pengantar Umum Pendidikan. Yogyakarta: Rineka Cipta, 1992.

Swanburg, Russel C, dan Ester Monica. Pengantar kepemimpinan \& manajemen keperawatan untuk perawat klinis. Jakarta: Penerbit Buku Kedokteran, 2000.

Wijianto, Wijianto, dan Ika Farida Ulfa. "Pengaruh Status Sosial dan Kondisi Ekonomi Keluarga terhadap Motivasi Bekerja bagi Remaja Awal (Usia 12-16 Tahun) di Kabupaten Ponorogo." Al Tijarah 2, no. 2 (31 Desember 2016): 190. https://doi.org/10.21111/tijarah.v2i2.742.

Wirahaji, I B., D. M. Priyantha Wedagama, dan P. Alit Suthanaya. "ANALISIS PENGARUH PENDAPATAN TERHADAP KEPEMILIKAN MOBIL DAN SEPEDA MOTOR PADA RUMAH TAGGA DI SEPANJANG KORIDOR TRAYEK TRANS SARBAGITA." Jurnal Spektran, 1 Januari 1970. https://doi.org/10.24843/SPEKTRAN.2014.v02.i02.p03.

Yudohusodo, Siswono. Transmigrasi: kebutuhan negara kepulauan berpenduduk heterogen dengan persebaran yang timpang. Cet. 1. Jakarta: Jurnalindo Aksara Grafika, 1998. 